\title{
Lengyel Tibor
}

\section{A ne bis in idem elv gyakorlati érvényesülésének korlátai Magyarországon az igazgatási és a büntetőjogi szankciók tükrében}

\section{The practical barriers regarding the principle of ne bis in idem in terms of the criminal and administrative law in Hungary}

\begin{abstract}
Absztrakt
Az Európai Unió Bíróságának kétszeres értékelés tilalmával kapcsolatban hozott döntései rámutattak arra, hogy hazánkban a közigazgatási és büntetőeljárások párhuzamossága, illetve a szankciók halmozódása alapvető forrása a ne bis idem elv érvényülésével kapcsolatban megjelenő jogértelmezési kérdéseknek. Jelen tanulmány célja, hogy napjaink jogalkalmazói gyakorlatán keresztül mutasson rá mindazon anomáliákra és ellentmondásokra melyek a ne bis in idem elv érvényesülésével kapcsolatban az adójog, a vámjog és a büntetőjog által alkalmazott szankciók viszonyrendszerében megmutatkoznak.
\end{abstract}

Kulcsszavak: ne bis in idem elv, tényállás azonosság, igazgatási eljárás, büntetô eljárás, szankció halmozódás

\begin{abstract}
Decisions of the Court of The European Union with regard to the prohibition of the so called twofold assessment has highlighted that in Hungary the parallelism of the administrative and criminal procedures and moreover the questions concerning the aggregation of the possible sanctions can be considered as fundamental source of legal interpretations of the principle of ne bis in idem. The aim of the recent study is to highlight the anomalies and contradictions in terms of the possible sanctions of tax, customs and criminal law - through the lens of law practitioners nowadays.
\end{abstract}

Keywords: the principle of ne bis in idem, identity of facts, administrative procedure, criminal procedure, aggregation of sanctions 


\section{Bevezetés}

A tanulmány elkészítésének alapvető célja, hogy korábbi tanulmányom (Lengyel, 2019) folytatásaként gyakorlati szempontból is bemutassa a ne bis in idem ${ }^{1}$ elv alkalmazásának komplex problémakörét és az arra adható lehetséges válaszokat. Jelen dolgozat feladata tehát, hogy napjaink jogalkalmazói gyakorlatán keresztül mutasson rá mindazon anomáliákra és ellentmondásokra, melyek a ne bis in idem elv érvényesülésével kapcsolatban az adójog, a vámjog és a büntetőjog által alkalmazott szankciók viszonyrendszerében napjainkban megmutatkoznak. Vitathatatlan, hogy az elmúlt évtizedekben a kétszeres értékelés tilalma következetesen érvényesült ugyan a büntetőjogban, viszont a jogalkalmazóknak egyre gyakrabban kellett szembesülniük azon megközelítéssel, miszerint a ne bis in idem elvböl fakadó tilalomra tekintettel nemcsak a büntetöjogi, de az azzal megegyező hatású határozatoknak is meg kellene tiltaniuk az újabb felelősségre vonás lehetőségét. Kérdés, hogy mennyiben hat majd ezen elv érvényesülésére az EU egyik új, büntetőjogi irányelve. ${ }^{2}$ Ezen megközelítés térnyerése azonban olyan alapvető kérdéseket vetett fel és vet fel napjainkban is, minek okán az elmúlt időszakban a tagállami bíróságok - az uniós jogszabályok egységes alkalmazása és az eltérő értelmezések elkerülése érdekében az Európai Unió Bíróságához (továbbiakban EUB) fordultak az uniós jog egy adott részének pontos meghatározása végett. Az EUB tárgyra vonatkozó ítéletei, így többek között a Bonda ügy ${ }^{3}$, az Orsi-Baldetti ügy ${ }^{4}$, a Fransson ügy ${ }^{5}$, valamint a Luca Menci ügy ${ }^{6}$ egyértelmúen rámutattak arra, hogy a közigazgatási és büntetőeljárások párhuzamossága ellenére, meghatározott és markáns rendezőelvek mentén egyértelmüen elhatárolható és érvényesíthető az Alapjogi Charta 50. cikkének rendelkezése. Ezen ítéletek azonban teljesen új helyzetet teremtettek, miután az EUB a büntetőjogi szankció fogalmát kiterjesztette a közigazgatási hatóság által alkalmazott büntető jellegü jogkövetkezményekre is, amellyel számtalan további olyan kérdést generált, melyek tekintetében várhatóan a gyakorlat fogja eldönteni, hogy jogrendszerünk mennyiben áll öszszhangban az EUB gyakorlatával (Molnár, 2017, 40.).

1 „Senki sem vonható büntetöeljárás alá, és nem büntethetö olyan büncselekményért, amely miatt az unióban a törvénynek megfelelóen már jogerősen felmentették vagy elitélték". (Az Európai Unió Alapjogi Chartájának 50. cikke)

2 Az Európai Parlament és a Tanács (EU) 2017/1371 irányelve (2017. július 5.) az unió pénzügyi érdekeit érintő csalás ellen büntetőjogi eszközökkel folytatott küzdelemröl. (Jacsó-Udvarhelyi, 2018)

3 C-489/10. sz. ügy (ítélethozatal 2012.06.05.), C-617/10. sz. ügy (itélethozatal 2013. 02. 26.)

4 C-217/15. és C-350/15. sz. egyesített ügyek (itélethozatal: 2017.04.05.)

5 C-617/10. sz. ügy (itélethozatal 2013. 02. 26.)

6 C-524/15. sz. ügy (ítélethozatal: 2018.03.20.) 


\section{A ne bis in idem elvének sérülése vámigazgatási, jövedéki és adóigazgatási eljárásokban a büntetőjogi szankciók fényében}

Az emberi jogok és alapvető szabadságok védelméröl szóló európai egyezmény (továbbiakban: EJEE) 7. kiegészítő jegyzőkönyvének 4. cikkében, valamint az Európai Unió Alapjogi Chartájának 50. cikkében rögzített kétszeres értékelés tilalmának EUB általi értelmezése, illetve az e tárgyban irányadónak tekinthető 8/2017. (IV. 18.) AB-határozat ${ }^{7}$ ellenére - a tényállás és az érintett azonossága esetén - napjainkban párhuzamosan folyhat Magyarországon adóigazgatási,jövedéki és vámigazgatási eljárás mellett büntetőeljárás, minek eredményeként mindkét eljárásban büntető jellegü szankciót alkalmazhat a hatóság. ${ }^{8}$ A szankciók halmozódása azonban dupla büntetés kiszabását teszi lehetővé, ami alapjaiban sértheti a ne bis in idem elvét, amelyekre a következő jogesetek mutatnak rá egyértelmüen.

\section{Vámigazgatási eljárás - Büntetőeljárás}

\section{Vámigazgatási eljárás}

A záhonyi határátkelőhelyen gépkocsival belépésre jelentkező személy és utasa szóbeli nyilatkozatot tett, miszerint csak a törvényesen behozható 40-40 szál cigaretta van a birtokukban. Nyilatkozatuk elfogadását követően a tételes vámvizsgálat során a gépjármü üzemanyagtartályából összesen 180 doboz, ukrán zárjegyes cigaretta került elő. A gépjárművet vezető személy a nem uniós jövedéki termék tulajdonjogát elismerte, azt a vámellenőrzés alól elvonta, a vám elé állítási és vámfelügyeletre vonatkozó kötelezettségének nem tett eleget ${ }^{9}$, így annak lefoglalását az eljáró hatóság elrendelte. ${ }^{10}$

Fenti tényállás alapján az eljáró vámigazgatási szerv -vámellenőrzéssel kapcsolatos kötelezettség megszegése miatt - az eljárás alá vont terhére jogerős határozatában 347.000 forint vámigazgatási bírságot szabott ki ${ }^{11}$, és ezzel egyidejüleg

7 Alkotmányos követelményként kerül meghatározásra, hogy ugyanazon személlyel szemben, azonos tényállás alapján a büntetőjogi felelősség megállapítása mellett nincs helye igazgatási (állatvédelmi) bírság kiszabásának.

8 Az EU vonatkozásában azonban más jellegü párhuzamok is felfedezhetök (Madai, 2011, 234. és Madai, 2010, 87-88.).

9 2017. évi CLII. 84. § (3) bekezdés e) pontjában meghatározott cselekmény.

10 2017. évi CLII. 90. § (1) bekezdésében foglalt kötelezettség.

11 2017. évi CLII. 84. § (12) bekezdése alapján a vámigazgatási bírság mértéke a vámteher összegének $200 \%$-a. 
elrendelte az Európai Unió területére jogellenesen bejuttatott 180 doboz, ukrán zárjegyes cigaretta elkobzását. Jelen eljárás a Vámkódex 84. § (1) bekezdése alapján általános gyakorlatként jelenik meg a vámigazgatási szervek eljárásaiban a vámellenőrzés alól elvont és belépés során felfedett csempészáru vonatkozásában.

A vámigazgatási eljárásban kiszabott büntető szankció (vámigazgatási bírság) és elkobzás alkalmazásán túlmenően a Nemzeti Adó- és Vámhivatal (továbbiakban: NAV) illetékes igazgatósága büntetőfeljelentést tett az eljárás alá vont ukrán állampolgár ellen a Büntető Törvénykönyvről szóló 2012. évi C. törvény 396. § (1) bekezdés a) pontjába ütköző és aszerint minősülő költségvetési csalás vétség elkövetésének gyanúja miatt a NAV nyomozóhatóságához.

\section{Büntetőeljárás}

A feljelentés alapján lefolytatott büntetőeljárás eredményeképpen az ügyben eljáró járásbiróság a terheltet - jogerős ítéletében - bünösnek találta költségvetési csalás vétségében. ${ }^{12} \mathrm{~A}$ bíróság indokolásában rámutatott arra, hogy a terhelt tisztában volt azzal, hogy adóköteles terméket szállit, ennek ellenére valótlan nyilatkozatot tett, amely magatartásával a költségvetésnek 173.467 forint vagyoni hátrányt okozott, mivel a cigaretta után 24.000 forint vámot, 107.470 forint jövedéki adót és 41.797 forint általános forgalmi adót kellett volna megfizetni. Ezen magatartásával a terhelt elkövette a Btk. 396. § (1) bekezdés a) pontjába ütköző és aszerint minősülő költségvetési csalás vétségét, amiért 100.000 forint pénzbüntetés és 6.350 forint bünügyi költség megfizetésére kötelezte.

\section{Jövedéki eljárás - Büntetőeljárás}

\section{Jövedéki eljárás}

A rendőrség munkatársai egy magyar állampolgár lakóingatlanán különböző tasakokban fogyasztási dohányt és magyar adójegyet nem tartalmazó cigarettát találtak, így az intézkedést a birtokolt termék jellegére tekintettel a NAV pénzügyőr járőrei átvették. Az elsődleges intézkedések során megállapítást nyert, hogy az ellenőrzéssel érintett személy összesen $7,9 \mathrm{~kg}$ fogyasztási dohányt és 30 doboz cigarettát tartott jogellenesen, adózatlan formában a birtokában ${ }^{13}$, me-

12 Nyíregyházi Járásbíróság 36. B. 492/2018./2. sz. ítélete.

13 A jövedéki adóról szóló 2016. évi LXVIII. törvény 74. § (1) bekezdésére figyelemmel. 
lyet elmondása szerint a piacon vásárolt saját használatra. A jövedéki ügyben eljáró hatóság megállapította, hogy az eljárás alá volt személy az adózatlan jövedéki termék megszerzésével jövedéki törvénysértést követett el, minek eredményeképpen jogerős határozatában 592.754 forint jövedéki bírságot szabott ki. ${ }^{14}$

A jövedéki eljárásban kiszabott büntetőszankció (jövedéki bírság) alkalmazásán túlmenően a NAV illetékes igazgatósága büntetőfeljelentést tett az eljárás alá vont magyar állampolgár ellen a Büntető Törvénykönyvről szóló 2012. évi C. törvény 379 . § (1) bekezdésébe ütközö orgazdaság elkövetésének gyanúja miatt a NAV nyomozóhatóságánál.

\section{Büntetőeljárás}

A feljelentés alapján lefolytatott büntetőeljárás eredményeképpen az ügyben eljáró Nyíregyházi Járásbíróság a terheltet - jogerős ítéletében - bünösnek találta orgazdaság büntett elkövetésében. ${ }^{15} \mathrm{~A}$ bíróság által megállapított tényállás szerint a terhelt ismeretlen személytöl és ismeretlen körülmények között, anyagi haszonszerzés végett megszerzett $7,9 \mathrm{~kg}$ fogyasztási dohányt és 20 doboz, magyar adó- és zárjegyet nem tartalmazó cigarettát, összesen 664.920 forint belföldi forgalmi értékben. Ezen magatartásával elkövette a Btk. 379. § (1) bekezdés b) pontjába ütközö, de a (3) bekezdés a) pontja szerint minősülő és büntetendő, nagyobb értékre elkövetett orgazdaság büntettét, amiért 200.000 forint pénzbüntetés és 5.000 forint bünügyi költség megfizetésére kötelezte.

Az ismertetett jogeseteket - a 8/2017. (IV. 18.) AB-határozat tükrében - értékelve a következö feltételek teljesülésének vizsgálata adhat választ azon kérdésre, hogy felmerül-e a ne bis in idem elv sérülése:

1.) személy azonossága,

2.) tényállás azonossága,

3.) szankcionáló eljárások kettőssége,

4.) a második határozat közül az egyik jogerős jellege.

Az első feltétel, azaz a személy azonossága mindkét esetben, tehát a vámigazgatási és büntetőeljárás, illetve a jövedéki és büntetőeljárás viszonyrendszerében is egyértelmüen megállapítható, hiszen ugyanazon magánszemély az eljárások és szankciók alanya az egyes eljárásokban. A további feltételeket vizsgálva ahhoz sem férhet kétség, hogy a lefolytatott közigazgatási és büntetőeljárások teljes tényállás-azonosságon alapulnak, így vitathatatlanul megállapítható a szank-

14 A jövedéki adóról szóló 2016. évi LXVIII. törvény 100. § (2) bekezdése alapján.

15 Nyíregyházi Járásbíróság 2.B. 244/2018./2. sz. ítélete. 
cionáló eljárások kettősége is. További közös jellemzője valamennyi duplikált eljárásnak, hogy a szankciót megállapító határozatok egyikének jogerős jellege minden esetben fennállt, így a negyedik feltétel is maradéktalanul teljesül.

Mindezek összegzéseképpen megállapítható, hogy napjaink gyakorlatában a ne bis in idem elvének érvényesülése a közigazgatási és büntetőeljárás viszonyrendszerében - az EUB ismertetett ítéleteinek, valamint a vonatkozó alkotmánybírósági határozat ellenére - jelentősen sérül a felvázolt esetekben.

\section{Adóigazgatási eljárás - Büntetőeljárás}

\section{Adóigazgatási eljárás}

Az adóhatóság által, általános forgalmi adónem tekintetében elrendelt ellenőrzés egyik megállapítása szerint a gazdasági társaság az általa üzemeltetett vendéglátóhely belső kivitelezési munkálataival kapcsolatban adólevonási jogot gyakorolt a könyvelésébe beállított és áfaanalitikájában is szerepeltetett 1.358.900 forint értékủ kivitelezési munkálatokról kiállított fiktív számla alapján. Ezen tényállás alapján az adóhatóság jogerős határozatában 289.000 forint általános forgalmiadó-különbözetet állapított meg, amelyet adóhiánynak minősített, így az adóbírság mértékét annak 50\%-ában állapította meg. A lefolytatott adóigazgatási eljárás mellett az adóhatóság büntetőfeljelentést tett az érintett gazdasági társaság cégjegyzésre jogosult tisztségviselöje ellen, a Büntető Törvénykönyvről szóló 2012. évi C. törvény 396. § (1) bekezdés a) pontjába ütköző költségvetési csalás elkövetésének gyanúja miatt a NAV nyomozóhatóságánál.

\section{Büntetöeljárás}

A feljelentés alapján lefolytatott büntetőeljárás eredményeképpen az ügyben eljáró járásbíróság a terheltet - jogerős ítéletében - bünösnek találta költségvetési csalás és hamis magánokirat felhasználásának vétségében. ${ }^{16} \mathrm{~A}$ bíróság által megállapított tényállás szerint a vádlott a gazdasági társaság irányítójaként abban a tudatban állította be a gazdasági társaság könyvelésébe a valótlan tartalmú bizonylatot, hogy annak adóbevallásban költségként történő feltüntetésével a társaság adófizetési kötelezettségét a számla áfatartamával csökkentse. A hiteltelen bizonylat könyvelésbe történő beállításával a vádlott a költségvetésnek áfaadónemben 289.000 forint vagyoni hátrányt okozott. Ezen maga-

16 Debreceni Járásbíróság 20. B. 1508/2016./19. sz. ítélete. 
tartásával a terhelt elkövette a Btk. 396. § (1) bekezdés a) pontjába ütköző és aszerint minősülő költségvetési csalás, valamint a Btk. 345. §-ába ütköző hamis magánokirat felhasználása vétségét, amiért 120.000 forint pénzbüntetés és 27.975 forint bünügyi költség megfizetésére kötelezte. Az adóigazgatási és büntetőeljárás viszonyrendszerét megjelenítő esetpélda azonban rámutat arra a gyakori esetre, amelyben a két jogviszony alanya elkülönül, miután a szankciót megállapító adóigazgatási eljárás alanya az adózó (a gazdasági társaság), míg a büntetőeljárás alanya a terhelt, azaz a gazdasági társaság tagja, illetve vezető tisztségviselője. Jelen esetben látszólag fel sem merülhet a kétszeres értékelés lehetősége, a személy azonossága, mint alapfeltétel nem teljesül, s ez kétséget kizáróan alátámasztást nyer az EUB Orsi-Baldetti ügyben hozott ítéletében. Az EUB ugyanis kimondta, nem ellentétes az EJEE 7. kiegészítő jegyzőkönyvének 4. cikkével, illetve a Charta 50. cikkével, ha ugyanazon tényállás miatt jogerősen adóbírságot szabtak ki, amennyiben azt jogi személyiséggel rendelkező társasággal szemben alkalmazták, míg a büntetőeljárások természetes személlyel szemben indultak.

Az ítélet tehát egyértelműen állást foglal abban, hogy a büntető eljárás alá vont és közigazgatási szankcióval sújtott személy azonossága alapfeltétel a ne bis in idem elvének érvényülése tekintetében, így ezen feltétel hiányában fel sem merülhet annak sérülése. Az EUB látszólag leegyszerüsítő megközelítése mellett további érvként hozható fel a büntetőjogi felelősség önálló elbírálásának, valamint a bizonyítékok szabad értékelésének elve, amely függetlenné teszi a büntetőeljárás során megállapított tényállást és annak alapjául szolgáló bizonyítékrendszert az adóigazgatási eljárásban megállapított tényállástól és a kiszabott szankciótól. A büntetőjogi felelősség elbírálásának önállósága azonban nem jelenti azt, hogy az egyéb eljárásokban feltárt bizonyítékok ne lennének felhasználhatók a büntetőeljárásban is, így a Be.-ben rögzített önálló elbírálás a felelösséggel kapcsolatos jogi kérdésekre vonatozik elsősorban.

A probléma azonban a hazai szabályozási környezetben lényegesen összetettebb, mintsem fenntartás nélkül elfogadhatnánk azon leegyszerüsített megállapítást, miszerint az adóigazgatási eljárás - büntető jellegü - szankcióval sújtott alanya az adózó, azaz a gazdasági társaság, míg a büntetőeljárás terheltje magánszemély (aki rendszerint a gazdasági társaság vezetője, vagy képviselője), minek okán a személyi egyezőség semmiféleképpen nem állhat fent. Az Art. ${ }^{17}$ ugyanis megteremti a lehetőségét annak, hogy azon esetekben, amikor az adózó az esedékes adót nem fizette meg, és azt tőle behajtani sem lehet, úgy az adó megfizetésére az adóbevétel csökkenését eredményező, valamint vagyoni

17 Az adózás rendjéről szóló 2017. évi CL. törvény 59. § (1) bekezdés d) és e) pont. 
hátrányt okozó büncselekmény elkövetője határozattal kötelezhető. Mindemellett meghatározza a gazdálkodó szervezet, a polgári jogi társaság adótartozásáért a vonatkozó anyagi jogi szabályok szerinti való felelősséget, amelynek eredményeképpen a helytállni köteles tag, illetve vezető tisztségviselő az adó megfizetésére szintén határozattal kötelezhető. Ennek fényében érzékelhető, hogy az egyes eljárások alanyainak elkülönülése inkább látszólagos, hiszen az adóigazgatási eljárásban megjelenő adózó, illetve gazdasági társaság mögött is rendszerint ugyanazon, az adó megfizetésére kötelezhető, illetve szankcionálható magánszemély áll, aki egyébiránt a büntetőeljárás alanya is. Ezen összefüggésben tehát kevésbé tünik konzisztens és kikezdhetetlen véleménynek az adóigazgatási és a büntetőeljárás alanyának ilyetén módon történő elkülönülése. Az eltérő alanyiság látszólagosságát egyébiránt teljes mértékben alátámasztja az adóhatóság számára biztosított jogszabályi lehetőség, amely a már hivatkozott Art. 59. § (1) bekezdésének d) és e) pontjára tekintettel a mögöttes felelösség alapján kötelezi a gazdasági társaság vezető tisztségviselőjét a társasággal szemben megállapított adóhiány megfizetésére. Összességében tehát valamenynyi mögöttes felelősség alapján történő kötelezés világosan rámutat arra, hogy az adóigazgatási eljárás és büntetőeljárás viszonyrendszerében az eltérő alanyiság nem értelmezhető egyértelmüen, miután az a hatályos eljárási szabályok alapján - a büncselekmény elkövetőjével szemben történő adóhatósági kötelezés esetén - legalább annyira tekinthető látszólagosnak, mint tényszerünek.

\section{Adóigazgatási eljárás és a jogi személlyel szemben alkalmazható büntetőjogi intézkedés viszonya}

A kétszeres értékelés tilalmával összefüggésben további kérdéseket vet fel az adóigazgatási eljárás és a büntetőeljárás során a jogi személlyel szemben alkalmazott intézkedések kapcsolata.

A jogi személlyel szemben alkalmazható büntetőjogi intézkedések szabályai - a Büntető Törvénykönyvön kívül eső módon - a 2001. évi CIV. törvényben kerültek lefektetésre. Ezen törvényi rendelkezés szerint jogi személlyel szemben szándékos büncselekmény elkövetése esetén - a terhelt ellen indított büntetőeljárásban - alkalmazható a jogi személy megszüntetése, a jogi személy tevékenységének korlátozása és a pénzbírság, mint büntetőjogi intézkedés, ha a büncselekmény elkövetése a jogi személy javára előny szerzését célozta vagy eredményezte, vagy a büncselekményt a jogi személy felhasználásával, annak tevékenységi körében követték el. A jogi személlyel szemben kiszabható pénzbírság legnagyobb mértéke a büncselekménnyel elért vagy elérni kívánt 
vagyoni előny értékének a háromszorosa, de legalább 500.000 forint. A hatályos szabályozás tehát lehetővé teszi ugyanazon gazdálkodó tekintetében a jogi személlyel szemben büntetőeljárás során alkalmazható - akár az okozott vagyoni hátrány háromszorosát kitevő - pénzbírság kiszabását, illetve ezzel egyidejüleg ugyanazon tényállás alapján adóigazgatási eljárásban adókülönbözet, késedelmi pótlék és adóbírság kiszabását egyaránt. Az ismertetett adóigazgatási és büntetőeljárásokban megjelenő általános gyakorlatot az Engel kritériumok, illetve a 8/2017. (IV. 18.) AB-határozat szempontrendszere szerint értékelve nem merül fel kétség az alkalmazott szankciók büntető jellege, a szankcióval sújtott személy, valamint a tényállás azonossága, illetve a szankciót megállapító határozatok egyikének jogerős jellege iránt. Mindezek fényében egyértelmüen megállapítható, hogy ezen jogviszonyok körében is megvalósul a ne bis in idem elvének sérülése.

\section{A büntetőeljárásban alkalmazott vagyonelkobzás, és az adóigazgatási eljárásban megállapított szankciók összefüggései}

A kétszeres elvonás tilalmára vonatkozó elvi kérdést a 95/2011. BK-vélemény értelemszerüen a büntetőügy oldaláról közelíti meg és rögzíti általános érvénynyel, miszerint „A költségvetési csalás elkövetöjével szemben akkor, ha a büncselekmény a költségvetésbe történö befizetési kötelezettséggel függ össze, a költségvetési bevétel csökkenésével azonos mértékü vagyonelkobzást kell elrendelni. A kétszeres értékelés tilalmára tekintettel azonban akkor, ha a kiesett bevétel megfizetésére, illetve jogosulatlanul igénybe vett kedvezmény megfizetésére az eljárni jogosult hatóság az elkövetöt, vagy azt a gazdálkodó szervezetet, amelyik azzal gazdagodott, már kötelezte, nincs helye vagyonelkobzásnak."

A büntetőeljárásban alkalmazott vagyonelkobzás és az adóigazgatási eljárásban megállapított adókülönbözet, illetve szankciók viszonyrendszerét azonban a 95/2011. BK-vélemény - a szankcióval sújtott személy azonossága esetén - sem teszi maradéktalanul egyértelművé, s annak érvényesülése számos gyakorlati problémát vet fel. A vagyonelkobzással és adójogi szankcióval sújtott személy azonossága ugyanis nemcsak magánszemély-magánszemély, hanem gazdálkodó szervezet-gazdálkodó szervezet viszonylatában is felmerülhet, minek tekintetében a Btk. 74. §-ának (2) bekezdése bír relevanciával, amelynek elsősorban a költségvetést károsító cselekményeknél van jelentősége. A Btk. hivatkozott rendelkezése szerint a gazdálkodó szervezettel szemben el kell rendelni a vagyonelkobzást, ha a büncselekmény elkövetéséből eredő vagyonnal e szervezet 
gazdagodott. A bírói gyakorlat szerint ugyanis az nem rendelhető el a vádlottal szemben arra a pénzösszegre, amellyel az általa elkövetett büncselekmény - adócsalás - kapcsán nem ő, hanem az általa vezetett gazdálkodó szervezet gazdagodott (BH 2013. 292.). A költségvetési csalás esetében tehát tisztázásra szoruló kérdés, hogy a cselekmény kapcsán a gazdasági társaság, avagy az azt képviselő elkövető gazdagodott. Amennyiben nincs adat arra, hogy a gazdasági társaságot terhelő adó megfizetésének elmulasztásával megtakarított összeg a gazdasági társaságot képviselő terhelthez jutott volna, úgy vagyonelkobzásra is csak a társasággal szemben kerülhet sor.

Ennek maradéktalan alkalmazhatósága elé azonban éppen a hivatkozott 95/2011. BK-vélemény gördít akadályokat, amely a kétszeres értékelés elkerülésének érdekében nem a kétszeres elvonás tilalmát határozza meg, amely a gyakorlatban is alkalmazható és végrehajtható elv, hanem megfogalmazza a kétszeres kötelezés tilalmát. A két tilalom között azonban óriási a különbség. A kétszeres elvonás tilalma egyéb feltételek mellett (személy, tényállás azonosság) praktikusan azt jelentené, hogy amennyiben a kiesett bevétel (adóhiány) megfizetésére az eljárni jogosult hatóság az elkövetőt, vagy azt a gazdálkodó szervezetet, amelyik azzal gazdagodott már kötelezte, és az a kötelezés eredményeként részben vagy egészben megtérült, úgy az adóigazgatási eljárásban megtérült összeg tekintetében vagyonelkobzásnak nincs helye. Ezzel szemben a hivatkozott BK-vélemény kizárólag a kötelezést határozza meg alapfeltételként, amelynek megléte kizárja a vagyonelkobzás alkalmazhatóságát. Ennek gyakorlati következménye, hogy egy adóhiányt és fizetési kötelezettséget megállapító adóhatósági határozat, függetlenül attól, hogy annak eredményeképpen bármiféle kármegtérülés (elvonás) megvalósult, az adóhatósági határozattal érintett vagyoni hátrány erejéig kizárja a büntetőeljárás során feltárt, értékkel bíró vagyonelemek tekintetében a vagyonelkobzást, amely közvetett módon a költségvetést ért károk megtérülésének is egyik lehetséges eszköze. Természetesen a vagyonelkobzás kizárása nem jelenti önmagában a kármegtérülés végleges ellehetetlenülését, hiszen a büntetőeljárás során feltárt és - a vagyonelkobzás törvényi feltételeinek megfelelő - lefoglalt, illetve zárolt vagyonelemek adóhatóság részére történő kiadása a jogerős kötelező határozat alapján esetenként megoldást nyújthat, viszont számos eset mutat rá arra, hogy a kétszeres kötelezés tilalma milyen anomáliákat eredményez az eredményes kármegtérülés érvényesíthetőségének tekintetében.

Ennek az esetnek példájául szolgálnak azon költségvetési csalás büncselekmények elkövetésének gyanúja miatt folytatott büntetőeljárások, amelyek során a nyomozó hatóság zár alá vette, illetve lefoglalta a felkutatott vagyonelkobzás alá eső vagyontárgyakat, amelyek a rendelkezésre álló adatok szerint az érintett gazdasági társaságok birtokában voltak, s azokkal a gazdálkodó szervezet 
gazdagodott. Figyelemmel arra, hogy a feltárt tények és adatok alapján adóigazgatási eljárás lefolytatásának is helye volt, a nyomozó hatóság - szignalizációs kötelezettségének eleget téve - értesítette az adóhatóságot az általa feltárt körülményekről.

A fenti kritériumok szerint folytatott konkrét büntetöügyben törvényességi felügyeletet ellátó ügyészség álláspontja szerint a nyomozás során nem lehet eltekinteni annak vizsgálatától, hogy az egyes gazdasági társaságok vonatkozásában az adóigazgatási eljárást az adóhatóság lefolytatta-e, illetve kötelezték-e a cégeket a büntetöügy tárgyát képező adóhiány megfizetésére. Amennyiben igen, úgy a kétszeres elvonás tilalmára tekintettel, a büntetőeljárásban az adóhatósági határozattal érintett vagyoni hátrány erejéig a vagyonelkobzás elrendelése kizárt, azaz a vagyonelkobzás biztosítása céljából lefoglalt vagy zárolt vagyontárgyak büntetőeljárás keretében történő előzetes értékesítésének elrendelésére sem kerülhet sor. Abban az esetben tehát, amennyiben az adóigazgatási eljárás eredményeként megtörtént az adófizetésre kötelezés, úgy erre tekintettel a vagyonelkobzás biztosítására lefoglalt vagyontárgyakat az adóigazgatási szerv részére, a lefoglalás megszüntetésével egyidejüleg, ki kell adni. Az ügyészi álláspontnak megfelelően a nyomozó hatóság beszerezte az adóhatósági fizetésre kötelezést megállapító - határozatokat, minek eredményeképpen, a lefoglalás megszüntetése mellett, a vagyontárgyak adóhatóság részére történő kiadása vált szükségessé, amely végrehajthatatlanná vált az érintett gazdálkodók felszámolásának időközbeni elrendelése miatt. Ez esetben ugyanis a gazdasági társaság vagyonával - az adóhatóságot megelőzően - kizárólag a felszámoló jogosult rendelkezni, így a lefoglalt vagyontárgyak kiadása is a felszámoló irányába valósult meg.

Hasonlóképpen foglalt állást a Debreceni Törvényszék, amely végzésében ${ }^{18}$ az adós gazdasági társaság tulajdonát képező, és a vagyonelkobzás érdekében zárolt vagyonelemeinek tekintetében a zár alá vételt - a kétszeres értékelés tilalmára tekintettel - feloldotta, és azok kiadásáról rendelkezett a vagyon felett rendelkezni jogosult felszámoló részére. A törvényszék indokolásában kifejtette, hogy az érintett - időközben felszámolás alá került - gazdasági társasággal szemben az adóhatóság a büncselekmény elkövetési értékénél jóval nagyobb összegủ adóbírságot szabott ki, így a zár alá vett bankszámlák és vagyontárgyak vonatkozásában -a 95/2011. BK-véleményre tekintettel - kizárt a vagyonelkobzás, minek eredményeként a zár alá vétel feloldása és a vagyontárgyak kiadása indokolt. A törvényszék, mint elsőfokú bíróság végzésének e részét a

18 Debreceni Törvényszék 17. B.568/2015./83. sz. 
Debreceni Ítélótábla helybenhagyta ${ }^{19}$, rámutatva arra, hogy a zár alá vétel feloldása a NAV határozatára és a kétszeres elvonás tilalmára tekintettel indokolt volt, s a bankszámlákkal, illetve vagyonelemekkel ezt követően a tulajdonos, illetve a felszámoló jogosult rendelkezni. Mindezen - napjainkra következetes gyakorlattá váló - jogalkalmazói álláspont kiinduló pontja és hivatkozási alapja az a 95/2011. BK-vélemény, amely a kétszeres elvonás tilalmára tekintettel magát az adófizetésre kötelezést, mint adóhatósági aktust tekinti vagyonelkobzás alkalmazását kizáró tényezőnek a gazdasági társasággal szemben, tekintet nélkül arra, hogy e kötelezés eredményeképpen bármiféle tényleges elvonás megvalósult-e. Az ismertetett esetpéldák egyértelmüen rámutatnak arra, hogy a kétszeres elvonás tilalmának érvényesülése érdekében - a hivatkozott BK-véleményre alapozva - olyan jogtechnikai megoldás vált gyakorlattá, amely a kettős elvonás elkerülése érdekében még az egyszeres elvonás lehetőségét is meghiúsítja a vagyonelemek felszámoló részére történő kiadásával. Elgondolkodtató, mennyire tükrözi a jogalkotói szándékot azon eljárás, amelynek keretében egy megtérülés nélküli adóhatósági kötelezés lehetővé teszi, hogy a vagyonelkobzás feltételeinek megfelelő, a NAV nyomozóhatósága által lefoglalt, illetve zárolt bankszámlákat, vagyonelemeket bocsát a felszámoló rendelkezésére, jelentősen korlátozva ezzel az okozott adóhiány, azaz a költségvetést ért károk megtérülési lehetőségét.

Ennek elsődleges oka az, hogy a felszámolás alatt lévő gazdasági társaság vagyona igen ritkán nyújt fedezetet a hitelezői igények kielégítésére, ezért a Cstv. az egyes hitelezöi követeléseket rangsorolja ${ }^{20}$, és azokat e sorrend megtartása mellett rendeli kielégíteni. Ennek eredményeképpen az adóhatósági kötelezéssel megállapított, de meg nem fizetett adótartozás immáron a felszámolási eljárásban, mint a NAV hitelezői igénye jelenik meg, a sorrendiségben elfoglalt helyére tekintettel a megtérülés minimális lehetőségével.

\section{Közigazgatási és büntetőjogi szankciók halmozódásának feloldása}

A fentiekben ismertetett esetpéldák markánsan rámutatnak arra, hogy a hazai jogalkalmazásban még igen kiforratlan, mi több, ellentmondásos a ne bis in idem elvének érvényesítése, amely esetenként túlzott megszorításokhoz, avagy éppen a kármegtérülés kizárásához, vagy akár az adóhatósági és büntetőjogi szankciók

19 Debreceni Ítélótábla Beüf.II. 51/2017/2. sz. határozata.

20 A csődeljárásról és a felszámolási eljárásról szóló 1991. évi XLIX. törvény 57. §. 
halmozódásához vezet. Ennek fényében fokozott jelentőséggel bír azon bírói szemlélet, amely felismeri az elv tényleges sérülését, és tudatosan, a hatályos jogi szabályozásnak megfelelve törekszik a kétszeres értékelésből adódó anomáliák elkerülésére. A kétszeres értékelés, illetve közigazgatási és büntetőjogi szankciók halmozódásának egyik legkritikusabb felülete jelenleg a jövedéki és büntetőeljárások viszonyrendszere, ahol a szankcióval sújtott személy, illetve a tényállások azonossága kétségbevonhatatlan, mint ahogyan a szankcionáló eljárások kettősége is. Ezen esetekben különös figyelmet érdemel, azon bírói jogalkalmazás, amely - akár példa nélküli megoldásokkal - törekszik a ne bis in idem elv gyakorlati érvényesítésére, amelyet a következő jogeset szemléltet. ANAV járőrei jövedéki ellenőrzés eredményeként eljárást kezdeményeztek adózatlan jövedéki termék megszerzése, birtoklása és jogellenes továbbértékesítése miatt egy magánszeméllyel szemben. A jövedéki eljárás eredményeképpen az adóhatóság 2016 augusztusában jövedéki törvénysértés elkövetése miatt 252.000 forint jövedéki bírság, 126.000 forint jövedéki adó és 44.487 forint általános forgalmi adó megfizetésére kötelezte az eljárás alá vont személyt, a Jöt. (2016. évi LXVIII. törvény a jövedéki adóról) 120. § (4) bekezdése alapján. Az ismertetett eljárás mellett a NAV illetékes igazgatósága büntetőfeljelentést tett az eljárás alá vont magyar állampolgár ellen a Büntető Törvénykönyvről szóló 2012. évi C. törvény 379. § (1) bekezdésébe ütközö, orgazdaság elkövetésének gyanúja miatt a NAV Bünügyi Igazgatóságához, amely a nyomozást a terhelttel szemben vádemelési javaslattal befejezte. A jövedéki ügyben hozott elsőfokú határozat ellen az eljárás alá vont fellebbezést nyújtott be, amelyben ismételten elismerte a jogsértés elkövetését, nem vitatta a határozat jogszerüségét, és kérte a jövedéki bírság elengedését. A fellebbezést elbíráló II. fokú hatóság 2016 novemberében jogerős határozatával az I. fokú hatóság határozatát helybenhagyta. Ezen döntés ellen az eljárás alá vont keresettel élt a Debreceni Közigazgatási és Munkaügyi Bíróság felé, jövedéki adóügyben hozott közigazgatási határozat felülvizsgálata tárgyában, arra hivatkozással, hogy a magyar jogszabályok szerint egy cselekmény elkövetése miatt nem lehet több eljárást is lefolytatni, és minden egyes esetben súlyos pénzbírság megfizetésére kötelezni. A közigazgatási per során beszerzésre került a Debreceni Járásbíróság büntető ügyben, 2017 júniusában meghozott jogerős ítélete ${ }^{21}$, amely a felperest bűnösnek mondta ki orgazdaság vétségében a Btk. 379. § (1) bekezdés b) pontja, valamint (2) bekezdés a) pontja alapján és 100.000 forint pénzbüntetésre ítélte. A büntetőügyben eljáró bíróság tehát nem vonta értékelés körébe a cselekmény elbírálását megelőzően jogerősen kiszabott jövedéki bírságot, mint közigazga-

21 Debreceni Járásbíróság 37.B.280/2017/15. sz. ítélete. 
tási szankciót. A közigazgatási bíróság ítéletében rögzítette, hogy a Debreceni Járásbíróság ugyanazon tényállás alapján állapította meg felperes bünösségét orgazdaság vétségében, mint amely az adóhatósági határozatnak az alapját is képezte. A bíróság álláspontja szerint a felperes ügyében megállapítható, hogy a büntetőeljárás és a közigazgatási eljárás lényegét tekintve ugyanazon tényállás alapján egymást megismételte, az adóhatóság a büntetöügyben tett terhelti vallomást értékelte döntése meghozatala során, és a közigazgatási, illetve büntetőeljárás között szoros anyagi és időbeli kapcsolat állt fenn. A bíróság az ügy összes körülményét mérlegelve, figyelemmel az EJEB és EUB döntéseire, illetve az Alkotmánybíróság 8/2017. (IV. 18.) AB-határozatára a ne bis in idem elv alkotmányos értékelése tárgyában, arra az álláspontra helyezkedett, hogy az adóhatóság által a felperessel szemben alkalmazott jövedéki bírság mértékét a büntető bíróság által kiszabott büntetés mértékével, azaz 100.000 forinttal csökkentette és 150.000 forint jövedéki bírságot állapított meg, ezt meghaladóan a keresetet elutasította. ${ }^{22}$

Az ismertetett jogesetet elemezve levonható a következtetés, hogy jelen esetben a büntető jellegü közigazgatási és büntetőeljárásbeli szankciók halmozása valósul meg ugyanazon személlyel szemben, ugyanazon tényállás alapján, amely a ne bis in idem elv korlátozásának minősülhet. A közigazgatási bíróság itéletének értékelése során azonban megkerülhetetlen az időbeliség kérdése annak tekintetében, hogy a vonatkozó döntés meghozatala (a ne bis in idem érvényesítése) valójában mely jogalkalmazó szervnek, a közigazgatási ügyben döntést hozó hatóságnak vagy bíróságnak, illetve a büntető hatalmat gyakorló szervnek (ügyészség, bíróság) lehet a kompetenciája. Ennek fényében némileg vitathatóvá válik az esetpéldában megjelenő közigazgatási bírósági ítélet, amely egy jogerős adóhatósági határozatban megállapított fizetési kötelezettséget csökkent egy időben később keletkezett, büntetőeljárásban hozott ítélet szankciójára tekintettel. Jelen esetben ugyanis - különös tekintettel az időbeliségre - megállapítható, hogy valójában nem az adóhatóság - utólag közigazgatási bíróság által megváltoztatott - határozata sértette a ne bis in idem elvét, hanem a büntetöügyben eljáró bíróság ítélete volt az, amelynek meghozatalával ténylegesen megvalósulhat a kétszeres értékelés a már korábban kiszabott szankciókra tekintettel. Jelen esetben tehát, egyetértve Elek Balázs álláspontjával (Elek, 2016, 237.), a büntető ügyekben eljáró bíróságoknak kellene egységes gyakorlatot kialakítaniuk abban, hogy az irányadó nemzeti szabályok fényében figyelembe kell e venni enyhítő körülményként a korábbi közigazgatási szankciót.

22 Debreceni Közigazgatási és Munkaügyi Bíróság 11.K.27.701/2016/21. sz. ítélete. 
E következtetés megalapozottságát támasztja alá a Debreceni Ítélötábla azon végzése ${ }^{23}$, amely a védői fellebbezést elbírálva helybenhagyta az első fokú bíróságként eljáró Nyíregyházi Törvényszék ítéletét ${ }^{24}$, amely elsőrendü vádlottat költségvetési csalás büntette miatt 4 év 6 hónap szabadságvesztésre és 5 év Magyarország területéről történő kiutasításra ítélte. A büntetés kiszabása körében előterjesztett fellebbezést az elsőrendủ vádlott védője arra alapozta, hogy az elsőfokú bíróság nem foglalkozott a kétszeres eljárás tilalmával, így nem tulajdonított semmilyen jelentőséget annak, hogy hogy elsőrendü vádlottat az adóhatóság ugyanazon tényállás alapján 244.000 .000 forint közigazgatási bírsággal sújtotta. A Debreceni Ítélőtábla hivatkozott végzése az elsőfokú itélet helybenhagyása mellett azonban indokolásában rámutatatott arra, hogy a költségvetési csalás miatt indult büntetőeljárásokban a bíróság által megállapított tényállásnak szükségszerüen utalni kell a közigazgatási eljárásban a tettazonosság körében értékelhető eljárás adataira. Így abban az esetben, ha ugyanazon cselekményért közigazgatási eljárásban a közigazgatási hatóság szankciót alkalmazott a terhelttel szemben, szükségszerü rögzíteni ezen tényadatokat, valamint a szankció nyomán megfizetett összeget is, amit a kár megtérülése körében figyelembe kell venni. A közigazgatási eljárásban hozott szankció figyelembe vétele így többirányú, részben az alkalmazandó szankció mértékére, részben az alkalmazott pénzügyi szankcióra, illetve a vagyonelkobzás alkalmazására is hatással lehet. Figyelemmel azonban arra, hogy a Nyíregyházi Törvényszék az elsőrendủ vádlottal szemben kizárólag szabadságvesztést alkalmazott, az ítélőtábla a szankció tekintetében az elsőfokú ítélet helybenhagyásáról rendelkezett, azonban szükségesnek tartotta a közigazgatási eljárás adataival a tényállást kiegészíteni, és a büntetés kiszabással kapcsolatos indoklást a ne bis in idem elv kapcsán pótolni.

Az ítélőtábla következtetéseivel egyetértve azonban további kérdésként merül fel annak gyakorlati alkalmazhatósága azon - esetpéldákkal is érintett - csekély vagyoni hátrányt eredményező büntetöügyekben, ahol a közigazgatási eljárásban kiszabott szankció mértéke, különösen jövedéki ${ }^{25}$ és vámigazgatási ${ }^{26}$ eljárásokban nagyságrendekkel haladja meg a kiszabásra kerülő büntetőjogi szankció várható mértékét. Ezen kérdés megválaszolása a gyakorlati alkalmazhatóság szempontjából azonban nem választható el a költségvetést károsító büncselekmények

23 Debreceni Ítélőtábla Bf. 589/2018/26. számú végzése.

24 Nyíregyházi Törvényszék 3.B.598/2017/45. számú ítélete.

25 A jövedéki adóról szóló 2016. évi LXVIII. törvény 100. § (2) bekezdése alapján a jövedéki bírság mértéke a központi költségvetésnek okozott vagyoni hátrány mértékének kétszeresétől ötszöröséig terjedö összeg.

26 2017. évi CLII. 84. § (12) bekezdése alapján a vámigazgatási bírság mértéke a vámteher összegének $200 \%$-a. 
értékhatárának alacsony voltától, amelynek - valós életviszonyokhoz igazodó - revíziója napjainkban egyre sürgetőbb igényként jelenik meg.

\section{Értékhatárok jelentősége a kétszeres értékelés tükrében}

A kétszeres értékelés tilalmát kifejező elv érvényesülése érdekében az egyes uniós tagországok különböző jogtechnikai megoldásokat alkalmaznak, amelyek eltérő módon ugyan, de jellemzően képesek biztosítani a párhuzamos eljárásokból adódó kétszeres értékelés, illetve a szankciók halmozódásának elkerülését, megfelelve ezzel annak a kívánt alapelvnek, hogy az azonos tényállások alapján indult igazgatási és büntetőeljárások ne párhuzamosan, hanem összehangoltan, egymásra épülve kerüljenek lefolytatásra.

Ezen alapelv érvényesülése érdekében párhuzamos eljárások lefolytatására rendszerint csak azon esetben kerülhet sor, ha a cselekmény súlya igazolja a büntetőeljárás megindításának szükségességét és a büntetőjogi felelősség megállapítását, valamint büntetés kiszabását a közigazgatási eljárástól függetlenül. Ennek okán válik kiemelkedő jelentőségüvé a büncselekmények elkövetési értékhatárának kérdése, hiszen a nyomozó hatóság - az adóigazgatási eljárás lefolytatása mellett - a csekélyebb költségvetési bevételkiesést eredményező ügyekben folytatott nyomozások során is ugyanazon általános eljárási protokollt folytatja ${ }^{27}$, mint a több száz milliós vagyoni hátrányt okozó büncselekmények nyomozása esetében. Magyarországon költségvetési csalás büncselekmény vonatkozásában - a jogalkotó jelenleg hatályos álláspontja szerint -100.000 forintot (nagyságrendileg 300 eurót) meghaladó adóhiány okozásánál már indokolt a cselekmény kriminalizálása, és az adóigazgatási eljárással párhuzamosan az igazságszolgáltatás teljes rendszerét átfogó büntetőeljárás lefolytatása. Szemléltetésképpen: ezen értékhatár átlépéséhez már elegendő akár 10 karton (100 doboz) adózatlan cigaretta, avagy $5 \mathrm{~kg}$ fogyasztási dohány birtoklása, amely esetekben az igen szigorú jövedéki szankciórendszer mellett megjelenik a büntetőjog eszközrendszere az állam büntetőjogi igényének érvényesítése érdekében. Ezen értékhatár irreálisan alacsony volta azonban mindamellett, hogy nagyságrendekkel megnöveli a párhuzamos eljárások számát, nem képviseli azon jogpolitikai célt sem, miszerint a cselekmény súlya és jellege teszi indokolttá a büntetőjog eszközeinek alkalmazását és a büntetőjogi felelősség megállapítását az adott tényállás tekintetében.

27 A kisebb vagyoni hátrányt okozó büncselekmények nyomozása során is azonos kötelezettségek terhelik. 
A leírtakra figyelemmel egyre elkerülhetetlenebb az elkövetési értékhatárok valós társadalmi és gazdasági életviszonyokhoz igazodó revíziója, amelynek eredményeképpen a hatóságok a jogsértések súlyához igazodó eszköztárral léphetnének fel a költségvetést károsító magatartásokkal szemben. Mindezek következtében hatékonyabban és egyértelmüen elkülönülhetne egymástól az adóigazgatási, illetőleg a büntető eszközrendszer alkalmazhatóságának feltételrendszere, ezáltal még inkább csökkenne a ne bis in idem elvébe ütköző joggyakorlat lehetősége.

\section{Befejezés}

A hazai joggyakorlat ellentmondásainak és tárggyal kapcsolatos anomáliának bemutatása nyilvánvalóvá teszik nemzeti szabályozásunk felülvizsgálatának szükségességét, amelynek elengedhetetlen része a költségvetést károsító magatartások elleni fellépésben szerepet vállaló hatóságok feladatrendszerének, valamint a teljes jogi környezet áttekintése. Napjainkban ugyanis - a költségvetési csalás sajátosságait némileg figyelmen kívül hagyva - nem igazán van jelentősége a cselekmény büntetőjogi megítélésében annak, hogy egy speciális jogviszony részeként sajátos a büncselekmény védett jogi tárgya, sértettje, a társadalomra veszélyesség foka, mint ahogy annak sem, hogy a költségvetési csalás esetében párhuzamosan jelen van egy hatékony és fajsúlyos eszköztárral rendelkező - büntető jellegű szankciók alkalmazását lehetővé tevő - adó- és vámigazgatási eljárás. Ezen összefüggésben kiemelt hangsúlyt kap az elkövetési értékhatár felemelése, minek következményeként az immáron nem kriminalizált cselekmények kontrollja az adóigazgatás rendelkezésére álló közigazgatási eszközökkel, hatékonyan müködő kiválasztási és kockázatkezelési rendszerrel, illetve célirányos ellenőrzési tevékenységen keresztül valósulhat meg. Az elkövetési értékhatárok revíziója tehát korántsem jelentené azt, hogy a csekély tárgyi súlyú adóelkerülő magatartások kikerülnek a hatóság látóköréből és ellenőrzési tevékenységéből, pusztán differenciált, a jogsértés súlyához igazodó eljárást, illetve jogkövetkezményt társít(hat) a jogalkotó az adott cselekményhez, amely további alapot biztosít a ne bis in idem elv érvényesüléséhez. Nem feledkezhetünk meg azonban arról a nem elhanyagolható körülményröl sem, hogy az adóigazgatási és büntető eljárások meglehetősen érzékeny viszonyrendszerébe beavatkozni kizárólag körültekintően, fokozott szakmai alapossággal lehetséges, tekintve, hogy költségvetésünk védelme és az adókikerülö magatartások elleni küzdelem eszközrendszerének jelenleginél kifinomultabb összehangolása kizárólag a költségvetési bevételek beszedési hatékonyságának zavartalansága mellett képzelhető el. 


\section{Felhasznált irodalom}

Elek B. (2016): A közigazgatási eljárás - büntető eljárás viszonya a ne bis in idem elvének tükrében. JURA, 2, 237.

Jacsó J. - Udvarhelyi B. (2018): Új irányelv az uniós csalások elleni büntetőjogi védelemröl. Magyar Jog, 6, 327-337.

Lengyel T. (2019): Az Európai Unió Bíróságának gyakorlata, valamint hazai szabályozásunk ellentmondásai a ne bis in idem elv érvényesülésének tekintetében. Belügyi Szemle, 3, 58-75.

Madai S. (2010): Gondolatok az Európai Közösségek pénzügyi érdekeinek megsértéséröl. Rendészeti Szemle, 2, 87-95.

Madai S. (2011): A csalás büntetőjogi értékelése. Budapest: HVG ORAC

Molnár G. M. (2017): Az adóigazgatási és büntetőeljárás kapcsolata. In: Domokos A. (szerk.): A költségvetés büntetőjogi védelme konferencia előadásainak szerkesztett változata. Budapest: Károli Gáspár Református Egyetem Állam- és Jogtudományi Kar, 40. 